University of Wollongong

Research Online

Faculty of Social Sciences - Papers (Archive) Faculty of Arts, Social Sciences \& Humanities

2012

What do Australian consumers think about current advertising standards?

Sandra Carol Jones

University of Wollongong, sandraj@uow.edu.au

Katherine Eagleton

University of Wollongong, kvp@uow.edu.au

Follow this and additional works at: https://ro.uow.edu.au/sspapers

Part of the Education Commons, and the Social and Behavioral Sciences Commons

Research Online is the open access institutional repository for the University of Wollongong. For further information contact the UOW Library: research-pubs@uow.edu.au 


\title{
What do Australian consumers think about current advertising standards?
}

\begin{abstract}
The concept of community standards is the cornerstone of advertising self-regulation in Australia. However, there is a dearth of research on current attitudes towards advertising and a virtual absence of such data in an Australian context. A questionnaire was developed to assess consumer attitudes towards advertising; respondents were 872 adults residing in New South Wales. We found high levels of concern regarding advertising standards in general and a consistent perception that advertising should not, for example, use coarse language or violent images, portray women or men as sex objects or show nudity, stereotype or make fun of groups of people, or convey messages that undermine parental authority. In relation to specific appeals and executional elements, although we identified numerous statistically significant demographic differences, there was a clear majority view as to what elements are unacceptable. That is, rather than the posited vocal 'moral minority', there is a consistency of views across the community on key issues of advertising standards. The finding that only a very small proportion of community-based respondents knew how to make a complaint to the correct organisation suggests that studies utilising complainant samples are unlikely to be representative of those who are concerned about advertising.
\end{abstract}

\section{Keywords}

standards, do, think, about, current, australian, advertising, consumers

Disciplines

Education | Social and Behavioral Sciences

Publication Details

Jones, S. Carol. \& Eagleton, K. (2012). What do Australian consumers think about current advertising standards?. Journal of Public Affairs, 12 (4), 315-325. 


\title{
What do Australian consumers think about current advertising standards?
}

\author{
Sandra C. Jones \& Katherine Eagleton
}

Centre for Health Initiatives, University of Wollongong

\begin{abstract}
ARTICLE SUMMARY
- The concept of community standards is the cornerstone of advertising self-regulation in Australia (as in many other countries)

- There is no statement - in the literature or in the regulatory framework - that defines community standards or clearly states how they are to be determined

- This study reports on a survey of 872 Australian adults in relation to their attitudes to advertising in general and to different types of appeals

- We find a marked consistency across demographic groups in relation to general attitudes to advertising

- While we found statistically significant differences in response to specific executional elements (e.g. in relation to age, gender and religion), there was still a consistently high level of agreement across groups

- We conclude that concerns about advertising standards are more widespread and homogeneous than previous studies may suggest
\end{abstract}

\section{FUNDING}

This research was funded by an Australian Research Council Discovery Grant awarded to the first author (DP0665652) 


\title{
What do Australian consumers think about current advertising standards?
}

\begin{abstract}
The concept of community standards is the cornerstone of advertising self-regulation in Australia. However, there is a dearth of research on current attitudes towards advertising; and a virtual absence of such data in an Australian context. A questionnaire was developed to assess consumer attitudes towards advertising; respondents were 872 adults residing in New South Wales. We found high levels of concern regarding advertising standards in general; and a consistent perception that advertising should not, for example, use coarse language or violent images; portray women or men as sex objects, or show nudity; stereotype or make fun of groups of people; or convey messages that undermine parental authority. In relation to specific appeals and executional elements, while we identified numerous statistically significant demographic differences, there was a clear majority view as to what elements are unacceptable. That is, rather than the posited vocal 'moral minority' there is a consistency of views across the community on key issues of advertising standards. The finding that only a very small proportion of community-based respondents knew how to make a complaint to the correct organisation suggests that studies utilising complainant samples are unlikely to be representative of those who are concerned about advertising.
\end{abstract}

Keywords: advertising; Australia; community standards 


\section{Introduction}

Consumer attitudes towards advertising were studied extensively in the United States between the 1930s and the 1970s; in a review of 38 of these studies, Zanot (1984) concluded that the Americans general attitudes towards advertising had become increasingly negative over this time period. However, there is a paucity of recent research and, more importantly, very little that has been conducted outside of the United States (O’Donohoe 1995).

Further, it is important to note that as O’Donohoe (1995) points out that much of this earlier research has identified some ambivalence in attitudes to advertising, suggesting that single-item measures of "approval" of advertising do not adequately address the underlying question of whether consumers find current advertising acceptable and if they do not, what aspects or issues are of concern.

It is generally agreed that there has been a steady increase in offensive advertising across all forms of media (Christy, 2006; Waller, 2004). Although advertisers have a social responsibility to ensure that their campaigns do not offend the general public (Waller, 2004), what is perceived as offensive in advertising is often subjective (Christy, 2006). In relation to controversial advertising, Boddewyn (1991) makes the distinction between 'hard' issues (those that focus on the deceptive nature of advertisements and the need to properly substantiate all claims made) and 'soft' issues (which are more difficult to define as they frequently reflect values and attitudes that are personally subjective, culturally related and historically changing). Thus any understanding of consumer attitudes towards advertising appeals, and regulation of such appeals, needs to be driven by current research conducted in the specific cultural context. 


\section{Studies from the US, Canada and Europe}

A key element of attitudes towards advertising is what O’Donohoe (1995) refers to as 'wariness of advertising', due to its perceived persuasive or deceptive intent. Calfee and Ringold (1998) reported on data from The Roper Center for Public Opinion Research archive, collected between 1964 and 1978, in which consumers were asked which of three statements they most agreed with; between 1964 and 1978 the proportion selecting “most advertising gives people information to help them decide what to buy" declined from $37 \%$ to $25 \%$, while the proportion selecting "most advertising frequently seeks to persuade people to buy things they don't need or can't afford” increased from 54\% to $71 \%$.

Shavit et al. (1998) conducted a nationally representative Computer Assisted Telephone Interviews survey of 1004 US adults (50.5\% female), investigating general attitudes towards advertising. They found that $51.1 \%$ reported sometimes or often feeling offended by an advertisement, $68.6 \%$ sometimes or often feeling misled by advertising, and $47.0 \%$ agreed that "most advertising insults my intelligence". However, just over half (51.5\%) agreed that in general they feel they "can trust advertising”. In relation to demographic differences, they found women were more likely than men to report feeling offended by advertising and to feel that there should be greater government regulation of advertising; younger people were less likely to report being offended, insulted, or misled by advertising than older adults; and those with lower levels of education more likely to report liking and trusting advertising messages.

From the few studies that have been conducted, it appears that attitudes to advertising (in terms of "liking" or "acceptance" of advertising in general) may be more 
positive outside of the United States (O’Donohoe, 1995); including studies from Canada (Crane, 1991) and Europe (Beatson, 1984; Bonnal, 1990).

\section{Studies from Australasia}

There have been several more recent studies conducted with student populations in a range of countries, including Australia and New Zealand, in relation to the perceived offensive of advertisements for 'controversial products' (Waller, 1999 [Australia]; Waller et al., 2005 [four countries including New Zealand]; Fam et al., 2004 [six countries including New Zealand]); and/or in relation to the offensiveness of specific executional elements, such as the use of racist imagery and sexual appeals (Waller, 1999; Waller et al., 2005; Liu et al., 2009 [three countries including Australia]).

\section{The Australian regulatory context}

Following the demise of the Advertising Standards Council in 1996, the major industry body, the Australian Association of National Advertisers (AANA), developed the Advertiser Code of Ethics (which applies to all forms of advertising), and established the Advertising Standards Board (ASB) and the Advertising Claims Board (ACB) to deal with complaints and breaches of this code. Under this self-regulatory system, the ASB deals with complaints about taste and decency in advertising, and the ACB deals with rival advertiser complaints (Baker et al., 1998). The authority of the two boards rests on the willingness of advertisers to adhere voluntarily to ethical standards. Section 2 of the AANA Code (the section administered by the ASB) includes clauses about discrimination and vilification, violence, sexuality and nudity, alarm and distress to children, obscene language, and health and safety. 
The concept of community standards is the cornerstone of advertising self-regulation in Australia, with the Advertising Standards Board (ASB) adjudicating complaints from the public based on 'prevailing community standards' (Australian Association of National Advertisers, 2009). However, it is concerning to note that the ASB does not explicitly define such standards nor do they conduct or communicate empirical research to determine the standards. Further, data on complaints to the Board (see Figure 1) shows a steady increase (both those deemed to fall within the charter of the Board, and those about issues outside the clauses of the Code); suggesting that a growing number of Australian consumers are concerned with current advertising standards.

*Place figure 1 about here*

There is a dearth of research on current attitudes towards advertising in general (that is, with data collected from members of the general population, rather than from specific groups of individuals); and a virtual absence of such data in an Australian context. Further, as O’Donohoe (1995) points out, the vast majority of the research that exists is from the United States, and frequently utilises student samples rather than more representative groups of consumers.

\section{Method}

A questionnaire was developed to assess consumer attitudes towards advertising in general and to the use of specific appeals and images in advertising messages. As recommended by O’Donohoe (1995) the development of items for the questionnaire was informed by consumer-based exploratory research. That is, while it included items 
that matched the clauses in the current self-regulatory advertising code, it also included items that originated from prior qualitative studies that were designed to identify messages and imagery of concern to Australian consumers (van Putten and Jones, 2007). In these previous studies a total of 20 focus groups were conducted to explore in depth consumer attitudes to advertising and perceptions of current advertising standards. Two series of focus groups were held; each consisted of 10 cohorts of adult members of the local Illawarra community. The first series of focus groups explored participants' attitudes and feelings towards advertising messages and content on a general basis. The second series had participants watch six recent advertisements (from those spontaneously identified by the participants in the first series), and then rate each one on a 13-item questionnaire using a 5 point Likert scale. The questionnaire included items such as the extent to which they believed each advertisement was personally (in)offensive, socially (un)acceptable, whether they believed the advertisement successfully marketed the product, as well as questions based on the AANA Code of Ethics.

The draft questionnaire was critically evaluated through a two-stage process. First, two focus groups were conducted in which participants read through and discussed the questionnaire, identifying any questions or response items that were unclear, confusing, or potentially leading. This process resulted in minor changes to the wording of some items, and the inclusion of some definitions and clarifications in the instructions. The revised questionnaire was then pilot-tested on a convenience sample of 25 people, with respondents asked to complete the questionnaire and then (on the last page) to note any items that they had found confusing or difficult to answer. All 25 
respondents completed all of the questionnaire items and no further modifications were suggested or made.

\section{Respondents}

An electronic database of names and addresses in the Illawarra, New South Wales Local Government Area (LGA) was purchased from a commercial research agency. This database consisted of 6,097 addresses (after data cleaning), and 4,000 were randomly selected to receive the survey. This sampling frame was considered to be more representative of the general population, given decreasing rates of landline telephone ownership. The survey was distributed in April 2008. The initial mailing resulted in the return of 656 completed surveys. Non-respondents were sent a reminder letter and a replacement in May 2008, resulting in the return of an additional 216 completed surveys (i.e., a total of 872 surveys, representing a response rate of $21.8 \%$ ).

Of the 872 returned surveys, $39.8 \%$ of respondents were male and $60.2 \%$ female. All respondents were aged 18 and over, and the age distribution was similar to that of the underlying population (ABS 2008), with 19.8\% aged under 35 years, 16.6\% aged 35-44, 20.9\% 45-54, 18.9\% 55-64, and 22.3\% aged 65 and over (see Table 1). Respondents self-identified as a range of religious affiliations (Table 1), which were categorised for the purpose of analysis into 'no religion' (23.7\%), 'Catholic' (23.4\%). ‘Anglican’ (20.5\%), ‘other Christian’ (21.5\%), and ‘other’ (10.9\%).

*Place table 1 about here*

The majority of respondents (71.0\%) had some post-secondary education (including bachelors degree or higher, trade certificate, or other certificate or diploma). A further 7.3\% reported completing a Higher School Certificate or equivalent (i.e., 12 
years of schooling); and the remaining 20.5\% completed some or no secondary education. Approximately $80 \%$ of the sample (77.6\% of males and $81.6 \%$ of females) stated they had children.

As a region, the Illawarra LGA has a demographic profile that is similar to that of the nation as a whole. Table 1 also provides a comparison of the key demographics between the Illawarra LGA and the national population (ABS, 2007), and between the LGA and the respondent sample. As shown in Table 1, there were few differences between our sample and the underlying population, with the exception of a higher proportion of those identifying as having no religion and a higher proportion of female respondents.

\section{Data analysis}

All data was entered into the statistical package SPSS Version 17.0 (IBM Corporation, Armonk, NY, USA) for analysis. Basic frequency analysis was completed for all variables; and chi-square tests were conducted to examine differences between demographic groups (e.g., gender, education, parental status) on each of the questionnaire items. For demographic variables with multiple categories and small numbers of respondents in some categories (e.g., religion, education), responses were recoded into a smaller number of variables.

\section{Results}

\section{Opinions about current Australian advertising}

Respondents were asked a series of seven questions about advertising, with responses on a 5 -point scale (where 1 = strongly disagree and 5 = strongly agree). 
As shown in Table 2, the majority of the respondents agreed or strongly agreed that 'there are sometimes advertisements in the media that people find offensive' (93.9\%), 'some advertisers intentionally create advertisements that they know will cause offence' (82.3\%), 'advertisements are sometimes misleading or deceptive about the product' (94.4\%), 'advertisements sometimes encourage behaviours in children that are inappropriate for their age' (90.9\%), and 'moral standards should be considered when creating advertisements’ (91.9\%).

*Place table 2 about here*

Conversely, only a small minority of respondents agreed that 'people who are offended by advertisements are too sensitive' (16.1\%); and approximately one-third (33.8\%) agreed that 'advertisers are sometimes unaware that their advertisements may be offensive'.

\section{Demographic differences in opinions about advertising}

As it has been suggested that there are differences in perceived offensiveness of advertising as a result of gender, age, and religious affiliation, we analysed responses separately by each of these demographic variables. For this analysis, responses were recoded into three categories: 'disagree' (1 or 2 on the 5-point scale), 'agree' (4 or 5), and 'neither' (3). The following section reports all significant differences between groups that were identified.

Gender 
Across the seven items, there was only one which showed significant differences between males and females: male respondents were more likely to agree that 'people who are offended by advertisements are too sensitive' ( $21.04 \%$ vs $12.45 \%, \chi^{2}=12.074$, $\mathrm{p}=0.002)$

Age

Across the seven items, there were three which showed significant differences between age groups. Older respondents were less likely to agree that 'people who are offended by advertisements are too sensitive’ (levels of agreement declined from $23.4 \%$ aged 1824 to $10.7 \%$ aged 75 and over; $\chi^{2}=64.477, \mathrm{p}<0.001$ ). Conversely, older respondents were more likely to agree that 'advertisements sometimes encourage behaviours in children that are inappropriate for their age' (increasing from $84.4 \%$ aged $18-24$ to 91.7\% aged 75 and over, $\chi^{2}=31.008, \mathrm{p}=0.006$ ), and that 'moral standards should be considered when creating advertisements' (increasing from 82.8\% aged 18-24 to 96.0\% aged 75 and over, $\chi^{2}=34.545, \mathrm{p}=0.002$ ).

\section{Religion}

Across the seven items, there were only two which showed significant differences by religious affiliation. Those who self-identified as Anglican or other Christian were less likely to agree that 'people who are offended by advertisements are too sensitive' (14.12\% and $11.9 \%$ respectively) than those who self-identified as catholic (17.4\% agreed) or no religion $(17.9 \%)\left(\chi^{2}=19.439, \mathrm{p}=0.013\right)$. Those who self-identified as not having a religion were less likely than any of the identified religious groups to agree 
that 'moral standards should be considered when creating advertisements' (83.2\% compared to $93 \% 97 \%$ for the other three groups; $\chi^{2}=28.381, \mathrm{p}<0.001$ ).

\section{Education}

Across the seven items, there were three which showed significant differences by respondents' level of educational attainment. Those who had completed a university degree were more likely to agree that 'there are sometimes advertisements in the media that people find offensive' (96.5\%) than in those with a high school education only (92.0\%) or who had completed other tertiary study $(93.1 \%)\left(\chi^{2}=10.300, p=0.04\right)$. However, they were less likely to agree that 'moral standard should be considered when creating advertisements’ (86.5\%) than those who had completed other tertiary education (92.1\%), who were in turn less likely to agree that those with a high school education only (97.4\%) $\left(\chi^{2}=29.028, \mathrm{p}<0.001\right)$. Those with a high school only education were less likely to agree that 'some advertisers intentionally create advertisements that they know will cause offence' $(74.4 \%)$ that those with a tertiary (86.5\%) or university (83.0\%) education $\left(\chi^{2}=20.292, p=0.001\right)$.

\section{Parental Status}

Across the seven items, there were two which showed significant differences between parents and non-parents. Parents were less likely to agree that 'people who are offended by advertisements are too sensitive' than nonparents $\left(13.6 \%\right.$ vs $25.4 \%$; $\chi^{2}=34.699$, p < 0.001); and more likely to agree that 'moral standards should be considered when creating advertisements' $\left(94.0 \%\right.$ vs $\left.83.6 \%, \chi^{2}=17.010, \mathrm{p}<0.001\right)$. 


\section{Media usage}

The survey included four questions regarding media use. Participants were asked if they regularly watched television, listened to the radio, read magazines or read newspapers. The majority (95.7\%) said they regularly watched television, read the newspaper (82.4\%), and listened to the radio (81.9\%); and approximately half (54.3\%) said they regularly read magazines. Affirmative responses were summed to give a cumulative media usage score, with a possible range of zero to four. The majority of respondents had a media usage score of four (40.9\%) or three (37.8\%), with only $4.2 \%$ receiving a score of zero or one. There were no significant differences for any of the items by respondents’ media usage level.

\section{Voicing their dissatisfaction}

The majority of respondents (89.9\%) responded affirmatively to the question “Are there rules about advertising in Australia?”, with only 1.3\% stating that there are no rules and 8.9\% unsure. However, when asked "Who can you complain to about an advertisement you object to?” the majority were unable to answer the question correctly. As shown in Table 3, there were a total of 882 responses (as some participants provided more than one answer). However, only 49 (5.6\%) of these identified the 'Advertising Standards Board'; an additional 75 (8.5\%) provided a response that was similar to this (such as “Advertising Standards Australia” or “Advertising Complaints Board”), suggesting that they could potentially locate the correct organisation if they wished to do so. Over a quarter of respondents (29.5\%) stated that they don't know who to complain to, and a similar number (27.2\%) stated that they would complain to the media outlet. 
*Place table 3 about here*

The perception that there are rules about advertising was not associated with respondent gender, religion, or parental status. However, awareness that there are rules about advertising was lower amongst the older respondents $\left(\chi^{2}=35.037, \mathrm{p}=0.001\right)$; those with no post-secondary education $\left(\chi^{2}=16.930, p=0.0 .002\right)$; those with lower levels of media exposure $\left(\chi^{2}=20.560, p=0.008\right)$.

Less than $10 \%$ of the respondents stated that they have ever made a complaint about advertising, with men slightly more likely to state that they had made a complaint about advertising than women (10.9\% compared to 7.7\%). This figure appears high, given data on complaint statistics, but includes complaints of any nature made to any person or organisation. Those who reported that they had made a complaint were asked who they had complained to. These 74 respondents provided 93 responses (i.e., some had complained to more than one organisation or made more than one complaint); with almost half reporting that the complaint had been made to the media outlet (48.4\%). The next most common response was “The Company Advertising” (18.3\% of mentions). The ASB was mentioned only eight times as the recipient of complaints made. There were no significant differences in reported complaining behaviour by gender, age group, religion, education level, parental status, or media use.

We then conducted the same analyses of responses to the survey items as we did for the demographic variables, and found that 'complainers' and 'non-complainers' differed in their responses to only one of the items: those who had previously made a 
complaint about advertising were less likely to agree that 'people who are offended by advertisements are too sensitive' $\left(16.6 \%\right.$ vs $\left.10.8 \% ; \chi^{2}=9.877, \mathrm{p}=0.007\right)$. That is, those who had previously complained (to any entity) did not differ from those who had not made such complaint in their perceptions of current standards of Australian advertising.

\section{Opinions about specific appeals in advertising}

Respondents' views on the use of specific appeals and images in the execution of advertising messages demonstrated a consistently high level of concern with the use 14 of the potentially 'controversial appeals' addressed in the questionnaire (Table 4). That is, respondents consistently disagreed with the use of coarse language (84.4\%), violence or violent images (84.3\%), portrayal of illegal behaviour (79.1\%), portrayal of unsafe behaviour (80.1\%), distressing or frightening images (67.4\%), nudity (77.1\%), portrayal of women as sex objects (80.3\%), portrayal of men as sex objects (78.8\%), stereotyping (81.1\%), celebrity endorsement of junk food products (69.3\%), and messages that directly target children (64.7\%) or undermine parental authority (89.8\%). Respondents were fairly evenly divided on the acceptability of the advertising unhealthy foods (54.6\%) and the use of messages that make fun of well known people (50.6\%). The majority agreed with the use of celebrities to advertise healthy foods (76.9\%) and other non-food products (58.8\%). The following section reviews the responses to each item, focusing on demographic differences identified.

*Place table 4 about here* 


\section{Gender}

Gender differences were identified on 10 of the 16 items. Male respondents were significantly more likely to agree that it is acceptable for advertising to: use coarse language $\left(\chi^{2}=9.419, \mathrm{p}=0.009\right)$; show violence $\left(\chi^{2}=8.990, \mathrm{p}=0.011\right)$; show unsafe behaviour $\left(\chi^{2}=10.440, \mathrm{p}=0.005\right)$; show distressing or frightening images $\left(\chi^{2}=9.333\right.$, $\mathrm{p}=0.009)$; show nudity $\left(\chi^{2}=14.327, \mathrm{p}<0.001\right)$; portray women as sex objects $\left(\chi^{2}=\right.$ 16.264, $\mathrm{p}<0.000)$; portray men as sex objects $\left(\chi^{2}=11.193, \mathrm{p}=0.004\right)$; stereotype or make fun of people $\left(\chi^{2}=8.500, \mathrm{p}=0.014\right)$; make fun of well known people $\left(\chi^{2}=\right.$ 18.656, $\mathrm{p}<0.001)$; and use celebrities to endorse junk food $\left(\chi^{2}=7.019, \mathrm{p}=0.030\right)$.

Age

Age-related differences were identified for 12 of the 16 items. Younger respondents (i.e., those aged under 45 years) were significantly more likely than older respondents (those aged 45 and over) to agree that it is acceptable for commercial advertising to: show violence $\left(\chi^{2}=41.419, \mathrm{p}<0.001\right)$; show unsafe behaviour $\left(\chi^{2}=59.189, \mathrm{p}<\right.$ $0.001)$; portray women as sex objects $\left(\chi^{2}=29.727, \mathrm{p}=0.008\right)$; portray men as sex objects $\left(\chi^{2}=39.012, \mathrm{p}<0.001\right)$; directly target children $\left(\chi^{2}=60.179, \mathrm{p}<0.001\right)$; and use celebrities to endorse junk food products $\left(\chi^{2}=108.746, \mathrm{p}<0.001\right)$,. Levels of agreement decreased linearly with age in relation to it being acceptable for advertising to show illegal behaviour $\left(\chi^{2}=33.991, \mathrm{p}=0.002\right)$; to stereotype or make fun of people $\left(\chi^{2}=33.247, \mathrm{p}=0.003\right)$; to make fun of well known people $\left(\chi^{2}=43.526, \mathrm{p}<0.001\right)$; to advertise unhealthy foods $\left(\chi^{2}=153.491, \mathrm{p}<0.001\right)$; and to undermine parental 
authority $\left(\chi^{2}=40.275, \mathrm{p}<0.001\right)$. Respondents aged 18-34 years were significantly more likely to agree that it is acceptable to use celebrities to endorse healthy food products than those aged over 35 years $\left(\chi^{2}=24.906, \mathrm{p}=0.036\right)$.

\section{Religion}

Religious affiliation was associated with significant differences on nine of the 16 items. Those who self-identified as having no religion were significantly more likely than those from any of the religious denominations to agree that it is acceptable for advertising to: use coarse language $\left(\chi^{2}=40.293, \mathrm{p}<0.001\right)$; stereotype or make fun of people $\left(\chi^{2}=17.054, \mathrm{p}=0.030\right)$; advertise unhealthy foods $\left(\chi^{2}=17.691, \mathrm{p}=0.024\right)$; and undermine parental authority $\left(\chi^{2}=17.627, \mathrm{p}=0.024\right)$. Those who identified as Christians ('Anglicans', 'Catholics’ and 'other Christians') were less likely to agree that it is acceptable to show nudity $\left(\chi^{2}=44.539, \mathrm{p}<0.001\right)$; to portray women as sex objects $\left(\chi^{2}=20.336, \mathrm{p}=0.009\right)$; to portray men as sex objects $\left(\chi^{2}=18.894, \mathrm{p}=0.011\right)$; and to make fun of well known people $\left(\chi^{2}=43.526, \mathrm{p}<0.001\right)$. Those who identified as Christians, and those who did not identify with any religious affiliation, were significantly more likely to agree with the use of celebrities to advertise non-food products than those whose religious affiliation was categorised as 'other' $\left(\chi^{2}=15.917, \mathrm{p}\right.$ $=0.044)$.

\section{Education}

Level of educational attainment was associated with significant differences on eight of the 16 items. For six of these items having a university education appeared to be 
associated with more liberal attitudes towards advertising. That is, those with a university education were significantly more likely to agree that it is acceptable for advertising to: use coarse language $\left(\chi^{2}=26.395, \mathrm{p}<0.001\right)$; show unsafe behaviour $\left(\chi^{2}\right.$ $=21.651, \mathrm{p}<0.001)$; show nudity $\left(\chi^{2}=18.483, \mathrm{p}<0.001\right)$; make fun of well known people $\left(\chi^{2}=20.895, \mathrm{p}<0.001\right)$; directly target children $\left(\chi^{2}=23.537, \mathrm{p}<0.001\right)$; and use celebrities to endorse non-food products $\left(\chi^{2}=11.000, \mathrm{p}=0.027\right)$. Those with a high school education only were significantly less likely to agree that it is acceptable for advertising to use celebrities to endorse junk food products $\left(\chi^{2}=27.492, \mathrm{p}<0.001\right)$; and those with a high school education only were less likely than those with other tertiary study to agree that it is acceptable to advertise unhealthy foods, who in turn were less likely to agree than those with a university education $\left(\chi^{2}=37.438, \mathrm{p}<0.001\right)$.

\section{Parental status}

Being a parent was significantly associated with responses on 15 of the 16 items. This is probably not surprising, given that many of the items relate to issues that have been raised in the literature and the popular press as potentially harmful to children's physical or social outcomes. For example, given the current level of concern over childhood obesity it is perhaps to be expected that parents are significantly less likely to agree that it is acceptable for advertising to advertise unhealthy foods $\left(\chi^{2}=26.906, \mathrm{p}<0.001\right)$; directly target children $\left(\chi^{2}=18.313, \mathrm{p}<0.001\right)$; and use celebrities to endorse junk food $\left(\chi^{2}=21.935, \mathrm{p}=0.002\right)$. Similarly, given frequently voiced concerns regarding the impact of media exposure on children it could be expected that parents are less likely to agree that it is acceptable for advertising to use coarse language $\left(\chi^{2}=317.936, \mathrm{p}<\right.$ 
0.001); show violence $\left(\chi^{2}=16.595, \mathrm{p}<0.001\right)$; show illegal behaviour $\left(\chi^{2}=16.996, \mathrm{p}<\right.$ 0.001); show unsafe behaviour $\left(\chi^{2}=18.732, \mathrm{p}=0.002\right)$; show distressing or frightening images $\left(\chi^{2}=9.361, \mathrm{p}=0.009\right)$; and undermine parental authority' $\left(\chi^{2}=7.884, \mathrm{p}=\right.$ 0.019). However, respondents who were parents were also significantly less likely to agree that it is acceptable for advertising to show nudity $\left(\chi^{2}=12.605, \mathrm{p}=0.002\right)$; portray women as sex objects $\left(\chi^{2}=23.442, \mathrm{p}<0.001\right)$; portray men as sex objects $\left(\chi^{2}=\right.$ 28.798, $\mathrm{p}<0.001)$; stereotype or make fun of people $\left(\chi^{2}=20.996, \mathrm{p}<0.001\right)$; make fun of well known people $\left(\chi^{2}=24.226\right.$, $\left.\mathrm{p}<0.001\right)$; and use celebrities to endorse healthy food products $\left(\chi^{2}=6.825, \mathrm{p}=0.033\right)$.

\section{Media usage}

Level of media usage was not associated with a significant difference on any of the items.

\section{Complainers and non complainers}

Having previously made a complaint about an advertisement was associated with differences on only two items; with those who had previously made a complaint less likely to agree that it is acceptable for advertising to show distressing or frightening images $\left(\chi^{2}=9.361, \mathrm{p}=0.009\right)$ and to show illegal behaviour $\left(\chi^{2}=12.646, \mathrm{p}=0.002\right)$.

\section{Discussion}

Our study findings bring together apparently disparate findings from previous research, demonstrating that the different findings, at least in part, a result of the level of 
specificity of the questions asked. As shown in Table 5, there were relatively few significant differences in responses to the "general advertising attitudes” survey items by demographic status, with only 11 differences identified across 42 comparisons. Further, the majority of these differences related to two items: 'people who are offended by advertisements are too sensitive' and 'moral standards should be considered when creating advertisements'. However, in relation to the use of specific messages and appeals, there were substantial differences in opinions on a number of the demographic variables.

*Place table 5 about here*

In relation to the specific executional elements, we found that gender, age and parental status were associated with differences in perceived acceptability across a range of message appeals and images. That is (consistent with previous research) women, older people, those with a religious affiliation, and those with children were more concerned about the use of 'controversial' appeals in advertising. Conversely, those with higher levels of education were less opposed to the majority of the messages and images examined in the survey.

However, these statistically significant differences should not be interpreted to mean that the issues examined are of concern to only a small segment of the population. Using a very conservative two-thirds majority rule (that is, to say that two-thirds of the population would have to disagree with the use of a message or image for it to be deemed in contravention of community standards) our results show that these standards should proscribe that advertising should not use coarse language, use violence or violent 
images, portray illegal behaviour, portray unsafe behaviour, show distressing or frightening images, show nudity, portray women as sex objects, portray men as sex objects, stereotype or make fun of groups of people, use celebrities to endorse junk food products, directly target children, or convey messages that undermine parental authority. Further, general attitudes towards advertising did not vary by gender, religion or parental status. This is consistent with findings from studies conducted in the US which used random or population samples (as opposed to the selective samples used in some of the Australian research on advertising complainants). For example, Bauer and Greyser (1968) found that attitudes to advertising were only slightly associated with respondent age, sex, income and education; and Durand and Lambert (1985) found that attitudinal factors and political beliefs were more explanatory than demographic variables.

It is also important to note that, even where demographic differences were identified, there was still a consistently high level of agreement (or disagreement). For example, in relation to there sometimes being advertisements in the media that people find offensive, which differed only by education level, the lowest level of agreement was $92.0 \%$; in relation to the perception that some advertisers intentionally create advertisements that they know will cause offence, which again differed only by education level, the proportion of agreement ranged from $74.4 \%$ to $86.5 \%$; and relation to the perception that advertisements sometimes encourage behaviours in children that are inappropriate for their age, which differed by age group of the respondent, agreement ranged from $82.5 \%$ (those aged 35 to 44 years) to $96.0 \%$ (those aged 75 years and over). That is, while there were statistically significant differences, in all three cases there was a clear majority agreement with the statement. 
Further, two of the three items that differed by educational attainment level related to advertisers' intent to offend or knowledge that they had done so, not to items regarding the presence or acceptability of offensive or inappropriate advertising. This suggests that there is not a difference in terms of moral standards, but rather of perceptions of the intentions of advertisers.

In relation to the two items which differed by multiple demographic variables, the same pattern emerged. For the view that moral standards should be considered when creating advertisements, the lowest level of agreement with this statement was $82.8 \%$ (people aged 18 to 24 years) and the highest was $98.7 \%$ (people aged 75 and over), with lesser degrees of variation within each of the other demographic variables identified as significant. For the question as to whether people who are offended by advertisements are too sensitive, the item with the greatest degree of variance in responses, the lowest level of agreement with this statement was 10.7\% (people aged 75 and over) and the highest was $25.7 \%$ (people aged 25 to 34 years), with lesser degrees of variation within each of the other demographic variables identified as significant again suggesting a consistent perception that being offended by advertising is a function of problems with the advertising itself rather than of the individual whose is offended.

\section{Limitations}

There are a number of limitations to this study which need to be acknowledged. The first is the use of a convenience sample of willing respondents to a mail-out survey; while our respondents were generally similar to the broader Australian population in terms of key demographics, we did have an over-representation of females and those identifying as having no religion. While the analysis did compare responses on these 
factors, care should still be taken in generalising these findings to the broader population.

The questionnaire included a number of terms that are open to subjective interpretation. We did not provide definitions of 'unhealthy' and 'healthy' food for example, as our previous qualitative research suggested that people's definitions differed and we did not want to impose our own definitions and thus bias the responses based on a single included or excluded product but rather allow people to respond in terms of their general view of the acceptability of advertising appeals. Similarly, we did not provide - or ask consumers to develop - a definition of 'community standards' as we sought to examine consumers’ perceptions of acceptable and unacceptable appeals. The definition currently provided by the Advertising Standards Board is as follows:

Prevailing community standards means the community standards determined by the Advertising Standards Board as those prevailing at the relevant time, and based on research carried out on behalf of the Advertising Standards Board as it sees fit, in relation to Advertising or Marketing Communications (Australian Association of National Advertisers 2009).

This does not provide guidance for consumers (or researchers). Thus, we used terms that both appear in the advertising code and are used by community members in their complaints to the Board (such as 'offensive').

Because of the exploratory nature of this study, and the logistical limitations inherent in a mail-out survey, we did not collect data on consumer responses to specific advertisements or test the acceptability of different executions (such as varying levels of sexism or graphic violence). Future research could provide more detailed guidance for advertisers and regulators by collecting data on responses to actual advertisements.

\section{Conclusion}


The lack of differences by demographics in relation to perceptions of the acceptability of current Australian advertising, based on a general population survey rather than a post-hoc analysis of the demographics of the limited sample (such as those who have complained to the Advertising Standards Board) suggests that concerns about advertising standards are more widespread and homogeneous than previous studies may suggest. Further, and perhaps most importantly, we identified very few differences between those who had previously complained about advertising and those who had not - both in terms of general perceptions of advertising acceptability and in terms of specific appeals and imagery. In relation to specific appeals and executional elements, while we identified numerous statistically significant demographic differences, there was a clear majority view across the sample as a whole as to what elements are unacceptable.

That is, rather than the posited vocal 'moral minority' there is a consistency of views across the community on key issues of advertising standards. This finding is consistent with Crosier and Erdogan's (2001) summary of findings from industrycommissioned, independently executed surveys conducted in the UK in 1998, which found that while only $1 \%$ of survey respondents had ever made a complaint, $68 \%$ reported that they had felt offended enough to consider complaining and 54\% found advertising generally not acceptable. A study of the profiles of complainants to the Advertising Standards Board (based on analysis of the postcodes of 1,210 complainants) (Volkov et al., 2005) concluded that complainants tend to have a higher income and higher level of education, and suggested this means that those more likely to be disadvantaged by "unacceptable” advertising may lack a voice in the current complaint system. In an earlier study which compared the attitudes of 300 people who 
had made a compliant to the ASB and 200 who had not, Volkov et al. (2002) cautioned that complainants may only be the 'tip of the social iceberg' and call for further research on consumer attitudes towards Australian advertising.

The results of the present study are particularly important in the context of our finding that only a very small proportion of community-based respondents were aware of the advertising standards board or knew how to make a complaint to that organisation. This could suggest, therefore, that studies utilising samples such as complainants are not representative of those who are concerned about advertising but rather of those who have the knowledge and resources to voice a formal complaint through the appropriate channels. The lack of differences on any of the items by media usage scores suggests that it is not that those with high levels of exposure are more accepting of inappropriate or offensive advertising.

The findings have important implications for advertisers (when deciding on appropriate advertising appeals) and for regulators (in beginning to clarify the standards the Australian community expects from advertisers). There are two important cautions for the advertising industry: first, that a substantial proportion of consumers are offended by current advertising appeals and executions; second, that continuing to utilize advertising messages that offend a proportion of the general public may - in the long-term - result in the introduction of a regulatory framework which is out of the hands of the industry.

For policy makers, this study adds to the growing body of evidence that the current self-regulatory system for advertising in Australia is failing to protect the public from messages and appeals that they find offensive or unacceptable. The ASB is composed of a group of people chosen to represent the community. However, despite 
its expansion to include community members and health representatives in recent years in response to concerns about its high representation of advertisers and media, current membership is still heavily skewed towards those working in media and/or arts fields. There are community members on the Board, although they tend to be those who are highly educated, and in a number of cases studying or working in the arts or creative arts field. Whereas these people are arguably very knowledgeable about mass media and the arts, they could not be said to constitute a broad spectrum of everyday Australians. Part of the problem arises from the very nature of this Board; a group of broadminded individuals who are repeatedly exposed to potentially offensive ads are likely to become jaded over time and to see the ads from a different perspective to the "average” Australian. There is a need to create a more reasonable yardstick for the measurement of prevailing community attitudes, to determine whether particular ads are within or outside community standards in relation to portrayals of sexuality, vilification, violence, and offensive language.

\section{References}

Australian Bureau of Statistics. 2008. 2006 Census Community Profile Series: Illawarra (statistical Region). http://www.censusdata.abs.gov.au/ABSNavigation (accessed 06 June 2010).

Australian Bureau of Statistics 2007, Census Community Profiles. Available at: http://www.censusdata.abs.gov.au/

Australian Association of National Advertisers 2009, Code of Ethics. Available at: http://www.aana.com.au/advertiser_ethics_code.html 
Baker MJ, Graham P, Harker D, Harker M. 1998. Marketing: Managerial Foundations. Macmillan:Sydney

Bauer R, Greyser S. 1968. Advertising in America: The consumer view. Boston: Harvard University Press.

Beatson R. 1984. The image of advertising in Europe. International Journal of Advertising 3: 361-367.

Boddewyn JJ. 1991. Controlling Sex and Decency in Advertising Around the World. Journal of Advertising 20(4): 25-35.

Bonnal F. 1990. Attitudes to advertising in six European countries. Admap. December: 19-23.

Calfee JE, Ringold DJ. 1998. Consumer scepticism and advertising regulation: What do the polls show? Advances in Consumer Research 15(1): 244-288.

Christy TP 2006. Females’ Perceptions of Offensive Advertising: The Importance of Values, Expectations, and Control. Journal of Current Issues and Research in Advertising, 28(2), p15-32.

Crane FG 1991. Consumers’ attitudes towards advertising: a Canadian perspective. International Journal of Advertising 10: 111-116.

Crosier K, Erdogan BZ. 2001. Advertising complainants: who and where are they? Journal of Marketing Communications 7, no. 2: 109-120.

Durand RM, Lambert ZV. 1985. Alienation and criticism of advertising. Journal of Advertising 14(3): 9-17.

Fam K-S, Waller DS, Erdogan BZ. 2004. The influence of religion on attitudes towards the advertising of controversial products. European Journal of Marketing 38(5/6): 537-555. 
Lui F, Cheng H, Li J. 2009. Consumer responses to sex appeal advertising: a crosscultural study. International Marketing Review 26(4/5): 501-520.

O’Donohoe S. 1995. Attitudes to advertising: a review of British and American research. International Journal of Advertising 14: 245-261.

Shavit S, Lowrey P, Haefner J. 1998. Public attitudes toward advertising: More favorable than you might think. Journal of Advertising Research July/August: 7-22. van Putten K, Jones SC. 2007. Putting the community back into community standards. Proceedings of the 2007 ANZMAC Conference, Dunedin, New Zealand, December $1-3$.

Volkov M, Harker D, Harker M. 2002. Opinions about advertising in Australia: a study of complainants. Journal of Marketing Communications 8: 229-242.

Volkov M, Harker D, Harker M. 2005. Who’s complaining? Using MOSAIC to identify the profile of complainants. Marketing Intelligence \& Planning 23(2/3): 296-312.

Waller DS. 1999. Attitudes towards offensive advertising: an Australian study. Journal of Consumer Marketing 16(3): 288-294.

Waller, DS 2004. 'What factors make controversial advertising offensive?: A preliminary study', Conference Proceedings, ANZMAC, July 2004.

Waller DS, Fam K-S, Erdogan BZ. 2005. Advertising of controversial products: a crosscultural study. Journal of Consumer Marketing 22(1): 6-13.

Willis JR, Ryans JK. 1982. Attitudes toward advertising: A multinational study. Journal of International Business Studies 13(3): 121-129.

Zanot EJ. 1984. Public attitudes towards advertising: the American experience. International Journal of Advertising 3: 3-15. 
Figure 1. Complaints to the Advertising Standards Board, 2001-2009

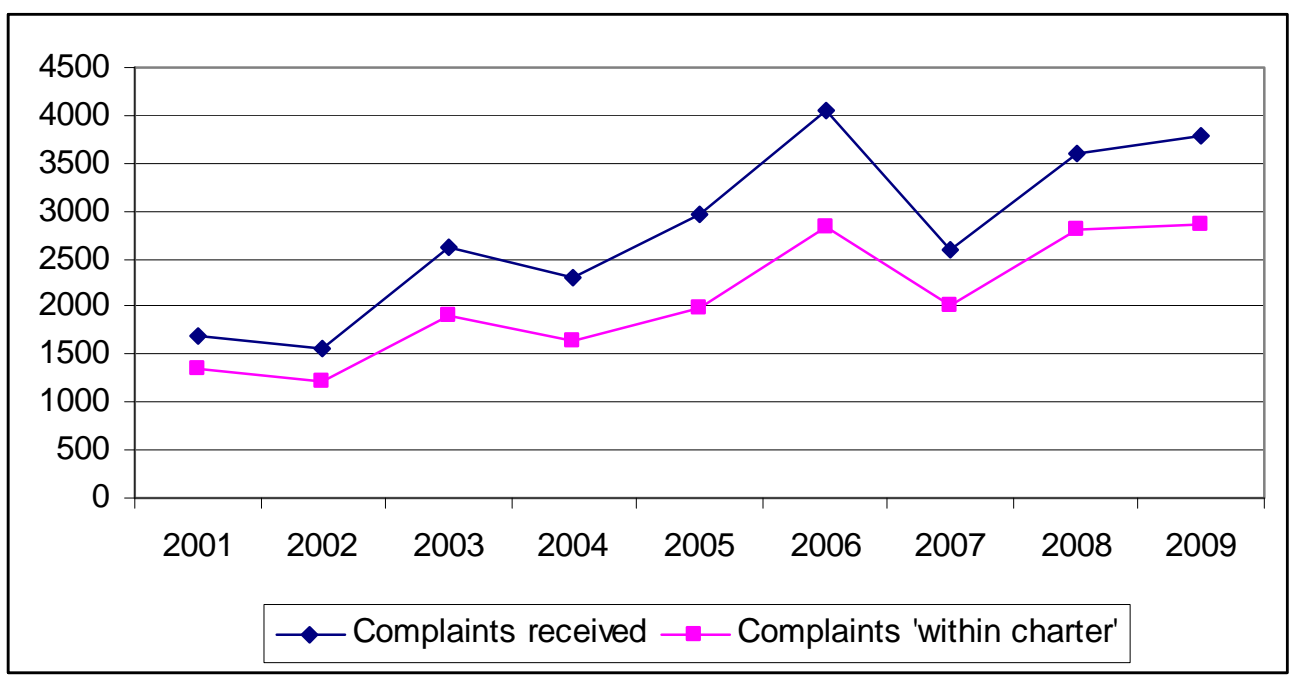


Table 1. Demographic characteristics of respondents (compared to the region and country)

\begin{tabular}{|l|c|c|c|}
\hline & $\begin{array}{c}\text { Survey respondents } \\
\text { (\%) }\end{array}$ & Illawarra LGA (\%) & Australia (\%) \\
\hline Gender & & & \\
\hline Female & 60.2 & 51.5 & 51.3 \\
\hline Male & 39.8 & 48.5 & 48.7 \\
\hline Age & & & 9.5 \\
\hline 18-24 years & 7.7 & 11.1 & 13.5 \\
\hline 25-34 years & 12.1 & 13.7 & 14.8 \\
\hline 35-44 years & 16.6 & 13.9 & 14.0 \\
\hline 45-54 years & 20.9 & 11.9 & 11.0 \\
\hline 55-64 years & 18.9 & 9.0 & 6.9 \\
\hline 65-74 years & 13.3 & 7.8 & 6.4 \\
\hline 75 years + & 9.0 & & 18.7 \\
\hline Religious Affiliation & & 15.2 & 25.8 \\
\hline No Religion & 23.7 & 27.1 & 18.7 \\
\hline Catholic & 23.4 & 26.3 & 1.5 \\
\hline Anglican & 20.5 & 1.5 & 5.7 \\
\hline Christian & 7.4 & 5.4 & 0.2 \\
\hline Uniting & 4.4 & 0.1 & 3.0 \\
\hline Other Christianity & 3.5 & 3.8 & 2.7 \\
\hline Presbyterian & 3.0 & 3.8 & 2.1 \\
\hline Orthodox & 1.9 & 0.8 & 1.7 \\
\hline Buddhism & 1.2 & 0.9 & 0.8 \\
\hline Islam & 1.0 & 0.2 & 1.3 \\
\hline Protestant & 0.8 & 0.7 & 0.7 \\
\hline Lutheran & 0.4 & 0.9 & 1.2 \\
\hline Hinduism & 0.1 & 9.2 & \\
\hline Other & 1.6 & & \\
\hline Did Not State & 7.1 & & \\
\hline & & & \\
\hline
\end{tabular}


Table 2. Proportion of respondents agreeing with each statement about current Australian advertising

\begin{tabular}{|c|c|c|c|c|c|}
\hline & $\begin{array}{c}\text { Strongly } \\
\text { Disagree } \\
\text { (\%) }\end{array}$ & $\begin{array}{c}\text { Disagree } \\
(\%)\end{array}$ & $\begin{array}{c}\text { Neither } \\
\text { Agree } \\
\text { nor } \\
\text { Disagree } \\
\text { (\%) }\end{array}$ & $\begin{array}{c}\text { Agree } \\
(\%)\end{array}$ & $\begin{array}{c}\text { Strongly } \\
\text { Agree } \\
(\%)\end{array}$ \\
\hline $\begin{array}{l}\text { There are sometimes advertisements in the } \\
\text { media that people find offensive }\end{array}$ & 1.0 & 2.0 & 3.1 & 60.9 & 33.0 \\
\hline $\begin{array}{l}\text { People who are offended by advertisements are } \\
\text { too sensitive }\end{array}$ & 13.6 & 50.2 & 20.1 & 13.3 & 2.8 \\
\hline $\begin{array}{l}\text { Advertisers are sometimes unaware that their } \\
\text { advertisements may be offensive }\end{array}$ & 13.1 & 40.6 & 12.5 & 28.7 & 5.1 \\
\hline $\begin{array}{l}\text { Some advertisers intentionally create } \\
\text { advertisements they know will cause offence }\end{array}$ & 1.6 & 5.6 & 10.5 & 56.5 & 25.8 \\
\hline $\begin{array}{l}\text { Advertisements are sometimes misleading or } \\
\text { deceptive about the product }\end{array}$ & 0.6 & 1.4 & 3.7 & 53.4 & 41.0 \\
\hline $\begin{array}{l}\text { Advertisements sometimes encourage } \\
\text { behaviours in children that are inappropriate } \\
\text { for their age }\end{array}$ & 0.2 & 2.8 & 6.1 & 47.6 & 43.3 \\
\hline $\begin{array}{l}\text { Moral standards should be considered when } \\
\text { creating advertisements }\end{array}$ & 0.4 & 2.0 & 5.9 & 44.4 & 47.5 \\
\hline
\end{tabular}


Table 3. Who participants believed they could complain to about advertising

\begin{tabular}{|l|c|c|}
\hline & $\begin{array}{c}\text { Number of } \\
\text { Mentions }\end{array}$ & $\begin{array}{c}\text { \% of Total } \\
\text { Responses }\end{array}$ \\
\hline Media Outlet & 240 & $27.21 \%$ \\
\hline Something Similar to ASB & 75 & $8.50 \%$ \\
\hline The Company Advertising & 73 & $8.28 \%$ \\
\hline The Ombudsman & 57 & $6.46 \%$ \\
\hline Advertising Standards Board/ASB & 49 & $5.56 \%$ \\
\hline “Broadcast” Tribunal/Control/Commission/Authority & 43 & $4.88 \%$ \\
\hline Other & 42 & $4.76 \%$ \\
\hline Member of Parliament & 23 & $2.61 \%$ \\
\hline Government Department & 22 & $2.49 \%$ \\
\hline Don't know & 258 & $29.25 \%$ \\
\hline
\end{tabular}


Table 4. Responses to the question "it is acceptable for advertising to..."

\begin{tabular}{|l|c|c|c|c|c|}
\hline \multicolumn{1}{|c|}{ Issue } & $\begin{array}{c}\text { Strongly } \\
\text { Disagree } \\
\mathbf{( \% )}\end{array}$ & $\begin{array}{c}\text { Disagree } \\
\mathbf{( \% )}\end{array}$ & $\begin{array}{c}\text { Neither } \\
\text { Agree } \\
\text { nor } \\
\text { Disagree } \\
\mathbf{( \% )}\end{array}$ & $\begin{array}{c}\text { Agree } \\
\mathbf{( \% )}\end{array}$ & $\begin{array}{c}\text { Strongly } \\
\text { Agree } \\
\text { (\%) }\end{array}$ \\
\hline Use coarse language & 47.52 & 36.91 & 8.65 & 4.61 & 2.31 \\
\hline Show violence or violent images & 54.90 & 29.41 & 8.19 & 6.00 & 1.50 \\
\hline Portray unsafe behaviour & 45.90 & 34.34 & 9.48 & 8.21 & 2.08 \\
\hline Portray illegal behaviour & 50.75 & 28.37 & 12.69 & 6.92 & 1.27 \\
\hline Show distressing or frightening images & 36.10 & 31.26 & 15.11 & 1.96 & 15.57 \\
\hline Show nudity & 39.36 & 37.74 & 14.27 & 7.13 & 1.50 \\
\hline Portray women as sex objects & 49.88 & 30.41 & 11.98 & 6.34 & 1.38 \\
\hline Portray men as sex objects & 48.73 & 30.07 & 12.56 & 7.03 & 1.61 \\
\hline Stereotype or make fun of people & 45.56 & 35.52 & 11.07 & 6.57 & 1.27 \\
\hline Make fun of well known people & 18.01 & 32.56 & 26.10 & 19.40 & 3.93 \\
\hline Directly target children & 32.53 & 32.18 & 18.22 & 15.92 & 1.15 \\
\hline Undermine parental authority & 58.11 & 31.65 & 6.33 & 2.30 & 1.61 \\
\hline Advertise unhealthy foods & 24.42 & 30.18 & 23.39 & 20.05 & 1.96 \\
\hline Use celebrities to endorse junk food & 35.64 & 33.68 & 19.95 & 9.69 & 1.04 \\
\hline Use celebrities to endorse healthy food & 2.89 & 4.17 & 16.09 & 53.13 & 23.73 \\
\hline $\begin{array}{l}\text { Use celebrities to endorse non-food } \\
\text { products }\end{array}$ & 3.94 & 7.52 & 29.75 & 52.08 & 6.71 \\
\hline
\end{tabular}


Table 5. Significant differences in responses by demographic groups

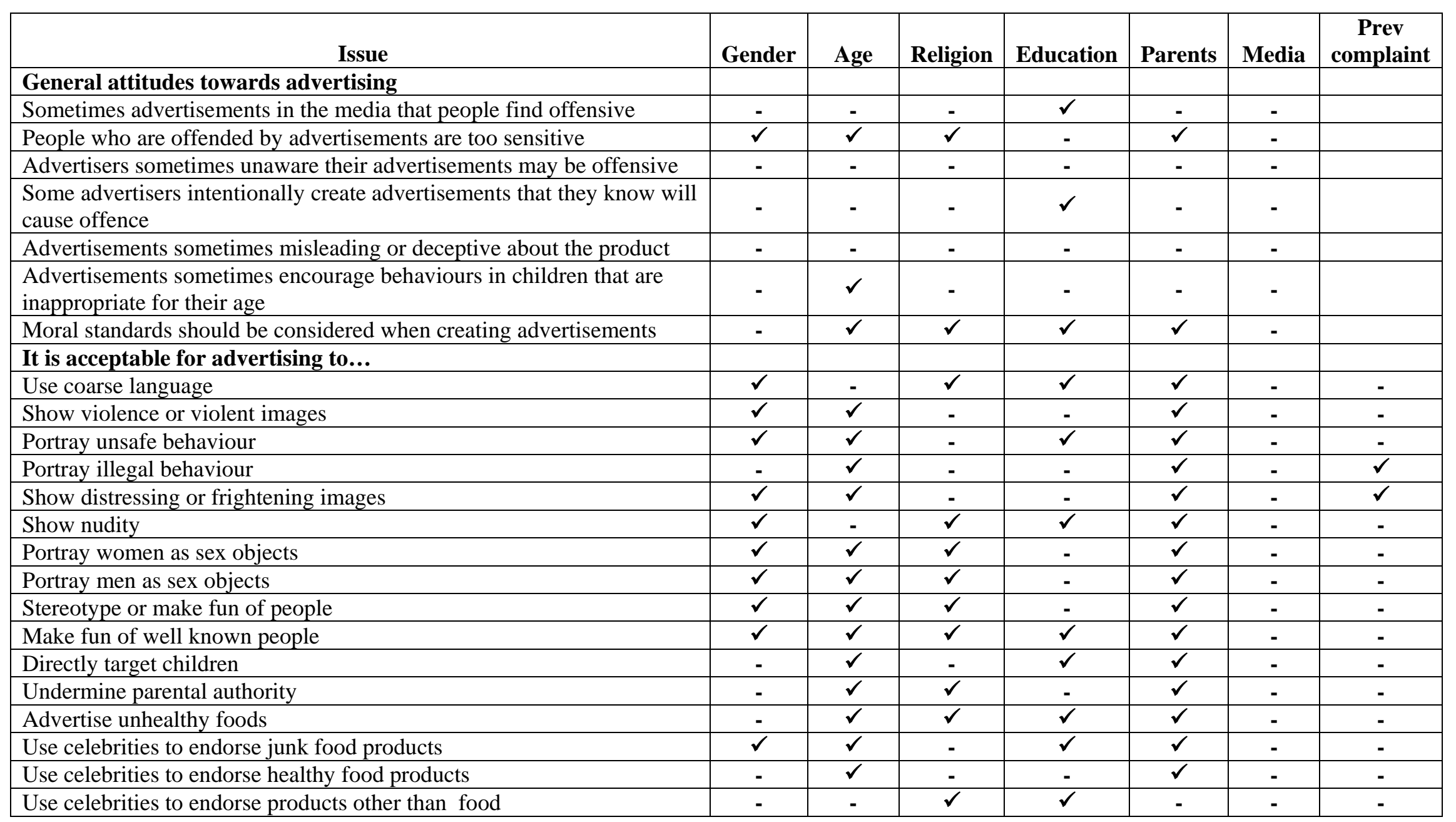

